\title{
Assessment of Trade Potential of Senegal and Morocco
}

\author{
Birahim Bouna Niang \\ Faculté des Sciences Economiques et de Gestion (FASEG), Université Cheikh Anta DIOP, Dakar, Senegal \\ Email: bmniang@gmail.com
}

Received 20 December 2015; accepted 15 January 2016; published 18 January 2016

Copyright (C) 2016 by author and Scientific Research Publishing Inc. This work is licensed under the Creative Commons Attribution International License (CC BY). http://creativecommons.org/licenses/by/4.0/

c) (i) Open Access

\begin{abstract}
Senegal and Morocco have significant advantages to develop bilateral trade. Trade between the two countries is in favor of Morocco. The estimation of the trade potential of the two countries based on an augmented gravity model reveals that this potential is underexploited vis-à-vis African trade partners and other parts of the World (Europe, Asia, and Latin America). The trade performances of Senegal and Morocco should be improved through the implementation of a supply policy and targeted support to exporting firms.
\end{abstract}

\section{Keywords}

Trade Potential, Export, Import, Gravity Model

\section{Introduction}

The deep integration of economies is one of the key features of the second half of the twentieth century. However, Africa is characterized by its low participation in international trade, its share amounting below the 5\% threshold. Therefore, intra-African trade is considered as one of the responses to marginalization and one of the ways of improving the resilience of African economies, in a context characterized by the recurrence of international shocks. Several initiatives of regional integration or of trade agreements have been taken by African countries in the different sub-regions of the continent. Thus, there are thirteen regional trade agreements and each African country is a member of at least one regional economic group [1]. Though the results of these trade agreements vary according to sub-regions [2], many of them did not meet the expectations; due to the narrowness of the range of exported products and the problem of "non-complementarity" of African trade, many countries have similar comparative advantages on the same product lines (Yeats, 1998).

Senegal and Morocco have considerable advantages (geographic proximity, cultural affinities, common language, etc.) to develop trade, even if they have some similarities (large share of the tertiary sector, exports of 
phosphates, and phosphate-based and fish products). These two countries with very strong cultural ties have signed a trade agreement in 1963, and an additional protocol in 1981. However, due to its commitments with the West African Economic and Monetary Union (WAEMU), Senegal suspended the implementation of the agreement since January 2000. In addition, Senegal had, since 2003, tariff preferences granted by Morocco to least developed African countries, as part of a royal initiative.

This paper aims to answer this question: what is the trade potential of Senegal and Morocco? The extent to which the two countries will make better use of their strengths and characteristics to develop trade flows between them and their main partners is the focus of this work.

After introducing the evolution of international trade from Senegal and Morocco in Section 2, Section 3 presents a synthetic literature on the gravity model. Finally, Section 4 is devoted to the estimation results of the trade potential of both countries.

\section{Evolution of International Trade of Senegal and Morocco}

Trade flows from Senegal and Morocco have experienced changes during the past 15 years, characterized by a reorientation of exports and imports of the two countries.

\subsection{Evolution of Exports}

Table 1 presents the evolution of exports from Morocco and Senegal. Regarding Morocco, the share of Africa in total exports increased from about 4\% in the second half of the 90s to 6\% over the period 2007-2011, while remaining relatively modest. Though European countries remain the main destination of Moroccan products, their share in total exports registered a decline of 8 points. In contrast, Morocco exports more to emerging Asian economies, the relative share of this group of countries in total exports increased by nearly 5 points.

Senegal exports grew much more significantly to African countries. Thus African countries, which have absorbed a quarter of Senegal exports in the second half of the 90s, represented nearly half of Senegal customers between 2007 and 2011. The reorientation of Senegal exports to African countries has been detrimental to traditional European partners, the share of these countries in total exports dropped by about 22 points. Exports to Asian emerging countries stabilized around $16 \%$ of total exports over this period.

Recent data (Figure 1) indicate that the main clients of Senegal are by order of importance Mali, the European Union, India, Switzerland and Guinea, while Morocco exports mainly to the European Union, India, Brazil, the United States and Singapore.

Regarding intra-African trade, in 2011 Morocco exports mainly to Algeria, Tunisia, Senegal, Mauritania and Egypt, while the main African countries customers of Senegal consist of Mali, Guinea, The Gambia, Côte d'Ivoire and Guinea-Bissau (Table 2).

\subsection{Evolution of Imports}

The evolution of imports from both countries (Table 3) is characterized by a stability of African imports, a decline in the relative share of imports from Europe, which is sharper for Senegal ( -10 points) than for Morocco ( -5.4 points) and a considerable increase in imports from Asian countries (9.4 points for Morocco and 8.7 points for Senegal).

In 2011, (Figure 2) the European Union, Nigeria, China, the United States and Turkey were the top five suppliers of Senegal, while Morocco imports came mainly from the European Union, China, the United States, Saudi Arabia and Russia.

Table 1. Destination of exports (\% of total).

\begin{tabular}{|c|c|c|c|c|c|c|c|c|}
\hline \multirow{3}{*}{ Countries } & \multicolumn{8}{|c|}{ Percentage of total exports } \\
\hline & \multicolumn{2}{|c|}{ Africa } & \multicolumn{2}{|c|}{$\begin{array}{c}\text { Developed countries of } \\
\text { Europe }\end{array}$} & \multicolumn{2}{|c|}{$\begin{array}{c}\text { Developed countries of } \\
\text { America }\end{array}$} & \multicolumn{2}{|c|}{$\begin{array}{l}\text { Emerging Asian } \\
\text { countries }\end{array}$} \\
\hline & $1996-2000$ & 2007-2011 & $1996-2000$ & 2007-2011 & $1996-2000$ & 2007-2011 & 1996-2000 & 2007-2011 \\
\hline Morocco & 4.1 & 6.0 & 71.6 & 63.5 & 4.9 & 4.4 & 10.7 & 15.4 \\
\hline Senegal & 25.4 & 48.0 & 44.5 & 22.9 & 1.0 & 0.6 & 16.3 & 16.0 \\
\hline
\end{tabular}

Source: UNCTAD (2013) [3]. 
Table 2. Intra-African exports, five major destinations by country.

\begin{tabular}{ccc}
\hline Countries & Destination of exports by order of importance & Part in total exports (\%) \\
\hline Morocco & Algeria, Tunisia, Senegal, Mauritania, Egypt & 44.6 \\
Senegal & Mali, Guinea, The Gambia, Côte d'Ivoire, Guinea-Bissau & 70.4 \\
\hline
\end{tabular}

Source: UNCTAD (2013) [3].

Table 3. Evolution of imports by origin.

\begin{tabular}{ccccccccc}
\hline \multirow{2}{*}{ Pays } & \multicolumn{9}{c}{ Percentage of total imports } \\
\cline { 2 - 9 } & \multicolumn{2}{c}{ Africa } & \multicolumn{4}{c}{$\begin{array}{c}\text { Developed countries of } \\
\text { Europe }\end{array}$} & $\begin{array}{c}\text { Developed countries of } \\
\text { America }\end{array}$ & $\begin{array}{c}\text { Emerging Asian } \\
\text { countries }\end{array}$ \\
\cline { 2 - 10 } & $1996-2000$ & $2007-2011$ & $1996-2000$ & $2007-2011$ & $1996-2000$ & $2007-2011$ & $1996-2000$ & $2007-2011$ \\
\hline Morocco & 5.3 & 5.6 & 56.8 & 51.4 & 7.7 & 7.6 & 14.2 & 23.6 \\
Senegal & 16.4 & 17.0 & 56.6 & 46.6 & 5.1 & 3.7 & 13.9 & 22.6 \\
\hline
\end{tabular}

Source: UNCTAD (2013) [3].

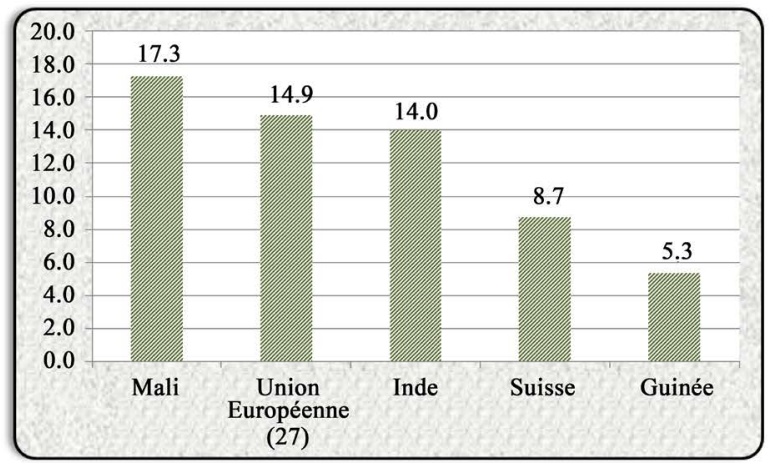

SENEGAL

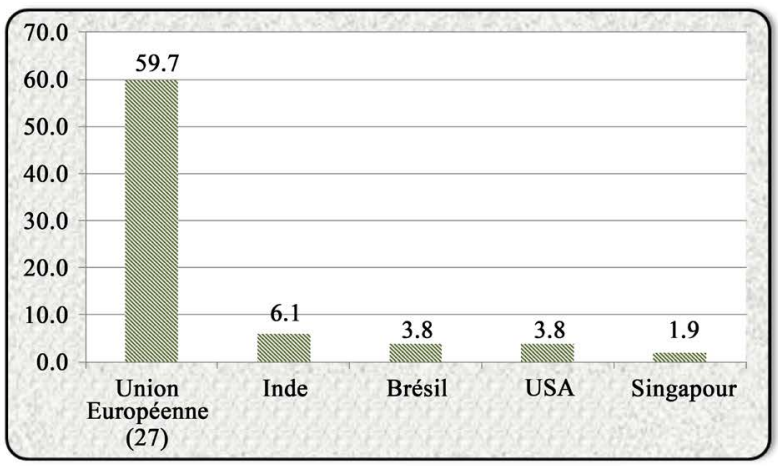

MOROCCO

Sources: Eurostat, International Financial Statistics (IMF), World Development Indicators (World Bank).

Figure 1. Exports to the five largest destinations by country in 2011 (\% of total exports).

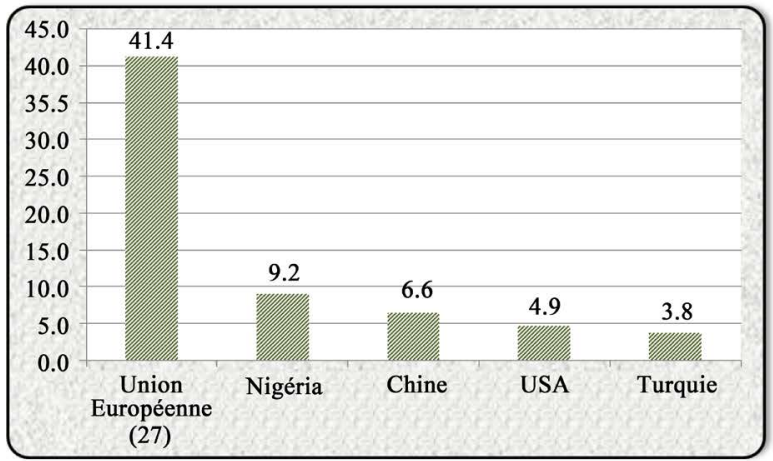

SENEGAL

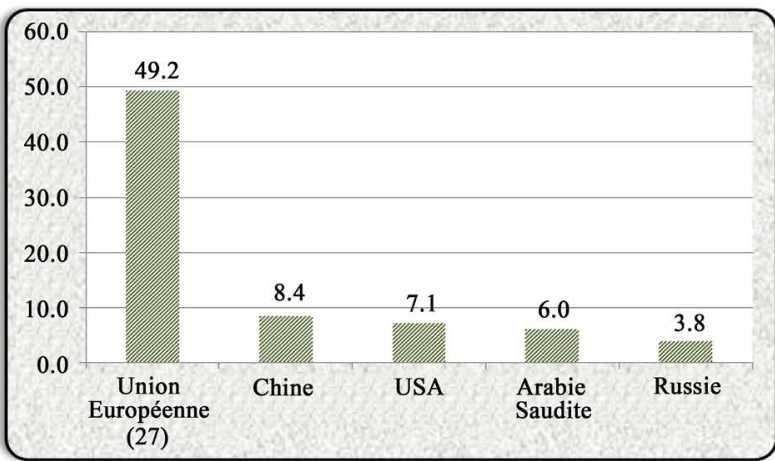

MOROCCO

Sources: Eurostat, International Financial Statistics (IMF), World Development Indicators (World Bank).

Figure 2. Imports from the five most important sources by country in 2011 (\%).

Regarding imports from Africa, Table 4 shows that they are mainly from Algeria, Egypt, Tunisia, Nigeria and South Africa for Morocco, while Senegal imports especially from Nigeria, Côte d'Ivoire, South Africa, Morocco and Tunisia.

Overall, Table 5 shows that Senegal is more and more orienting its trade to African countries than Morocco. Between the periods 1996-2000 and 2007-2011, the share of trade with African countries in the Gross Domestic Product (GDP) has increased from 10\% to nearly 15\% in the case of Senegal, while that of Morocco settled be- 
low the threshold of $4 \%$.

\subsection{Evolution of Trade between Senegal and Morocco}

Trade between Senegal and Morocco is characterized by an imbalance in favor of Morocco. The Senegal coverage rate of imports from Morocco is relatively low (Figure 3). Its average amounted to $14 \%$ over the period 2001-2010. Though it had an erratic profile, it reached a peak of 22\% in 2002 and has followed a downward trend since 2006. The lowest coverage rate (8\%) occurred in 2008.

Faced to the dynamism of exports of Morocco, Senegalese exporters are less aggressive and do not manage to significantly penetrate the Moroccan market.

\section{Assessment of the Trade Potential with the Gravity Model: A Literature Review}

Since the seminal work of Tinbergen [4], the gravity model has been intensively applied to international trade. The idea is to apply a model of international trade similar to gravity model of Newton in Physics. According to the universal law of gravitation of Newton, attraction between planets is positively related to their mass and inversely proportional to the distance between them. It can be formulated as follows:

$$
A_{i j}=\frac{M_{i} \cdot M_{j}}{D_{i j}}
$$

where:

$A$ : Attraction between planets;

Table 4. Intra-African imports, the five largest sources by country in 2011.

\begin{tabular}{ccc}
\hline Countries & Five main sources of imports in order of importance & Part in total imports (\%) \\
\hline Morocco & Algeria, Egypt, Tunisia, Nigeria, South Africa & 90.7 \\
Senegal & Nigeria, Côte d'Ivoire, South Africa, Morocco, Tunisia & 88.4 \\
\hline
\end{tabular}

Source: UNCTAD (2013) [3].

Table 5. Intra-regional African trade (\% of GDP).

\begin{tabular}{cccc}
\hline Countries & $\mathbf{1 9 9 6 - 2 0 0 0}$ & $\mathbf{2 0 0 1 - 2 0 0 6}$ & $\mathbf{2 0 0 7 - 2 0 1 1}$ \\
\hline Morocco & 2.3 & 2.3 & 3.5 \\
Senegal & 10.0 & 13.5 & 14.8 \\
\hline
\end{tabular}

Source: UNCTAD (2013) [3].

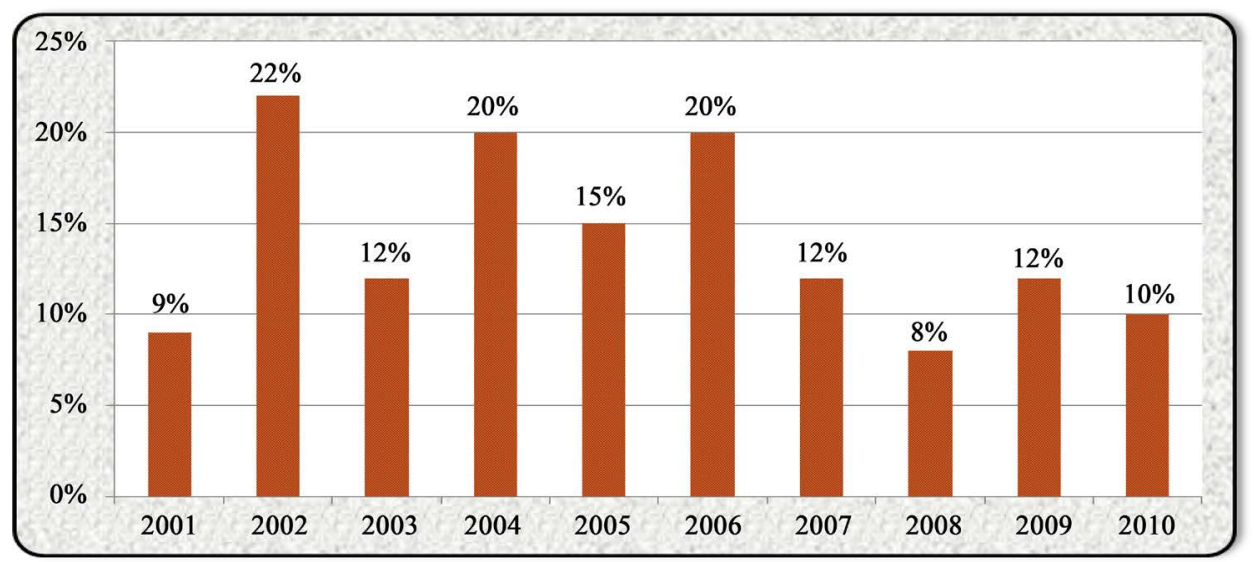

Source: Ministry of Commerce of Senegal and CMPE ${ }^{1}$, author's calculations.

Figure 3. Senegal rate of coverage of imports from Morocco by Senegal exports to Morocco.

${ }^{1}$ CMPE: Moroccan Export Promotion Center. 
$M$ : Mass of planets;

$D$ : Distance between planets.

The basic gravity model applied to international trade, due to Tinbergen [4], postulates that trade flows depend on the size of economies measured by GDP and transportation costs approximated by the distance between countries linked by trade relationships:

$$
X_{i j}=A\left(\frac{Y_{i} \cdot Y_{j}}{D_{i j}}\right)
$$

where:

$X$ : Exports;

A : Constant;

$Y$ : Gross domestic product.

Thus, the size of economies acts as a trade attraction force, while transportation costs are detrimental to international trade. The augmented version of the gravity model takes into account other factors that influence trade:

- The level of economic development measured by per capita income (which influences trade through consumers purchasing power);

- Cultural factors (common language, common colonizer) that influence consumption patterns;

- Common border and trade agreements (that reduce barriers to trade);

- etc.

The augmented gravity model can be specified as follows [5]:

$$
X_{i j}=\alpha_{0} y_{i}^{\alpha_{1}} y_{j}^{\alpha_{2}} Y_{i}^{\alpha_{3}} Y_{j}^{\alpha_{4}} D_{i j}^{\alpha_{5}} P_{i j}^{\alpha_{6}} \mathrm{e}^{u_{i j}}
$$

where:

$X_{i j}$ : Exports of country $i$ to country $j$;

$y$ : Per capita income;

$Y:$ GDP;

$D$ : Distance between partner countries;

$P$ : Dummy variable measuring trade preferences;

$u$ : Error term.

Despite a lack of theoretical foundations, the gravity model had a great empirical success because of its ability to predict bilateral trade. Then, several studies have been developed to address knowledge gap of the gravity model. Thus, Anderson [6] and Bergstrand [7] hold the Armington assumption of product differentiation by country of origin. As part of the analysis considered, all goods are exchanged. Each country involved in the exchange consumes a little of all goods produced in other countries. Transportation costs, considered as "iceberg" costs, reduce trade flows.

The restrictions of the Armington assumption are lifted as soon as we reason in a context of monopolistic competition [8]. Business location is then endogenous and countries specialize in the production of a range of goods.

The gravity model was also derived following different approaches to explain international trade. Thus, Deard off [9] used the law of factor proportions, while Anderson and Wincoop (2003) have used a model of monopolistic competition. Helpman et al. (2008) as well as Chaney (2008) used a theoretical framework characterized by product differentiation and firm heterogeneity.

The gravity model has been subjected to several applications. It can be used to measure the impact of economic integration experience in the volume of trade or the impact of borders on trade flows. Given its functional form, it can be used to calculate the trade potential between partner countries. This model is used to estimate the trade potentials of Senegal and Morocco.

\section{Calculation of Trade Potential}

The approach used to calculate the trade potential is composed of several steps [5]:

1) estimating a gravity model on a sample of countries;

2) calculation of simulated trade flows from the estimation results of the model;

3) calculating the adjusted simulated flows; 
4) computation of trade potential as the average of gross simulated flows and adjusted simulated flows. Adjusted exports, denoted $X_{i j}^{*}$, are given by the following equation:

$$
\begin{gathered}
X_{i j}^{*}=\frac{\hat{X}_{i j}^{*}\left(\sum_{j} X_{i j}-X_{i j}\right)}{\sum_{j} \hat{X}_{i j}-\hat{X}_{i j}} \\
X_{i}^{*}=\sum_{j} X_{i j}^{*}
\end{gathered}
$$

$\hat{X}$ : Simulated exports.

\section{Estimation of the Trade Potential of Senegal and Morocco}

The model used is an augmented version of the gravity model. It is specified as follows:

$$
\begin{aligned}
\operatorname{LogX}_{i j t}= & a_{0}+a_{1} \operatorname{LogGDP}_{i t}+a_{2} \operatorname{LogGDP}_{j t}+a_{3} \text { LogD }_{i j t}+a_{4} \text { Logenerg }_{i j t}+a_{5} \text { Logenerg }_{j t} \\
& +a_{6} \text { LogSuperf }_{j}+a_{7} \text { Logcredit }_{i t}+a_{8} \text { WAEMU }+a_{9} \text { Contiguity } \\
& +a_{10} \text { Langcom }+a_{11} \text { Langloc } a_{12} \text { Coloncom } a_{13} \text { Indust }_{i j}+u_{i j t} .
\end{aligned}
$$

The specification retained is in the log-linear form. The dependent variable is the level of exports $\left(X_{i j}\right)$ and it is assumed to be explained by factors found in literature:

- Production level measured by GDP of partner countries that measures the size of the market influences positively trade flows;

- The distance (D) is a proxy for transportation costs and has a negative impact on trade flows;

- The surface (Superf) of countries participating in trade is an important indicator of domestic market which influences negatively international trade;

- A dummy variable (contiguity), taking the value 1 or 0 depending on whether countries share border or not captures border effect;

- Cultural factors are taken into account through dummy variables representing the existence of a common official language (Langcom);

- Membership in the West African Economic and Monetary Union (WAEMU) which is measured by a dummy variable.

In addition, other variables that could facilitate (or hinder) trade are also taken into account such as:

- Credit to private sector in percentage of GDP (credit);

- Industrialization level (indus) measured by the share of industry in GDP;

- The average per capita power consumption (kg of oil) (energ) reflecting the level of economic development;

- Inflation which provides information on macroeconomic stability.

The study includes 14 countries of origin and 81 countries of destination from different regions of the world (Table 6). Trade data are from the United Nations COMTRADE database, while other data are extracted from the CEPII data base and from the World Bank database (World Development Indicators). The data cover the years 2005 and $2006^{2}$.

The model was estimated by the ordinary least squares method. With the application of the stepwise method ${ }^{3}$, some non-significant variables were not included in the analyses. The results of the gravity model are presented in Table 7.

The results show that GDP of partner countries, cultural factors measured by the common language and common colonizer, the existence of border between countries, credit availability to the private sector, energy consumption in the country of origin have positive effect on trade flows. In contrast, the distance between partner countries, which reflects transportation costs, surface or size of domestic market of the importing country, macroeconomic instability captured by inflation rate have negative impact on bilateral trade flows.

The findings regarding the variables measuring industrialization and energy consumption in the importing country is somewhat counterintuitive to the extent they reveal that these variables affect negatively trade flows.

\footnotetext{
${ }^{2}$ To limit the effects of annual fluctuations, the average of 2005 and 2006 was selected.

${ }^{3} \mathrm{~A}$ command of Stata software allows applying the stepwise method by gradually eliminating variables whose coefficients are not statistically significant.
} 
Table 6. Sample of countries ${ }^{4}$.

\begin{tabular}{|c|c|c|c|}
\hline \multirow{2}{*}{$\begin{array}{c}\text { Countries of origin } \\
\text { Benin }\end{array}$} & \multicolumn{3}{|c|}{ Countries of destination } \\
\hline & Morocco & United Kingdom & Syria \\
\hline Côte d’Ivoire & South Africa & Italy & Iran \\
\hline Cameroun & Nigeria & China & Russia \\
\hline Cape Verde & Ecuador & Tanzania & Benin \\
\hline Algeria & Portugal & Israel & Libya \\
\hline Gabon & Pakistan & Bangladesh & Soudan \\
\hline Ghana & Colombia & Suede & Ukraine \\
\hline Kenya & Algeria & Ghana & Comoros \\
\hline Morocco & Denmark & Egypt & Swaziland \\
\hline Namibia & Singapore & Canada & Greece \\
\hline Senegal & Mozambique & Indonesia & Philippines \\
\hline Togo & Czechoslovakia & Germany & Qatar \\
\hline Tunisia & Lebanon & Angola & Korea \\
\hline \multirow[t]{14}{*}{ Tanzania } & Viet Nam & The Gambia & Venezuela \\
\hline & Japan & Congo & Brazil \\
\hline & Côte d'Ivoire & Saudi Arabia & Ireland \\
\hline & Turkey & Kuwait & Poland \\
\hline & United Arab Emirates & Spain & Uruguay \\
\hline & France & Cameroon & Argentine \\
\hline & Equatorial Guinea & Malaysia & Yemen \\
\hline & Gabon & Peru & Botswana \\
\hline & Togo & Senegal & Bosnia Herzegovina \\
\hline & Kenya & Zambia & Georgia \\
\hline & Thailand & Hungary & Chile \\
\hline & Sri Lanka & Mexico & Namibia \\
\hline & Netherlands & Cape Verde & Nepal \\
\hline & Tunisia & Finland & Bolivia \\
\hline
\end{tabular}

Table 7. Estimation results of the gravity model.

\begin{tabular}{cc}
\hline Dependent Variable & logexport \\
\hline Logdist & $-1.663^{* * * *}$ \\
& $(0.119)$ \\
logpib_o & $0.959^{* * *}$ \\
& $(0.0891)$ \\
logpib_d & $1.137^{* * *}$ \\
& $(0.0750)$ \\
logsuperf_d & $-0.207^{* * *}$ \\
& $(0.0541)$ \\
contig & $0.992^{* *}$ \\
& $(0.393)$ \\
langcom & $0.843^{* * *}$ \\
& $(0.195)$ \\
\hline
\end{tabular}

${ }^{4}$ The sample was selected so that it meets the criterion of representativeness and contains the main export partners of Senegal and Morocco from different regions of the world. 


\begin{tabular}{|c|c|}
\hline Continued & \\
\hline \multirow{2}{*}{ colcom } & $0.674^{* * *}$ \\
\hline & $(0.228)$ \\
\hline \multirow{2}{*}{ credit_d } & $0.00944^{* * *}$ \\
\hline & (0.00219) \\
\hline \multirow{2}{*}{ inflation_o } & $-0.0118^{*}$ \\
\hline & $(0.00628)$ \\
\hline \multirow{2}{*}{ logindus_o } & $-0.0236^{* *}$ \\
\hline & $(0.00984)$ \\
\hline \multirow{2}{*}{ logenerg_o } & $0.648^{* *}$ \\
\hline & $(0.266)$ \\
\hline \multirow{2}{*}{ logenerg_d } & $-0.741^{* * *}$ \\
\hline & $(0.0969)$ \\
\hline \multirow{2}{*}{ Uemoa } & $1.279^{* * *}$ \\
\hline & $(0.481)$ \\
\hline \multirow{2}{*}{ constante } & $10.31^{* * *}$ \\
\hline & (2.013) \\
\hline Nombred'observations & 886 \\
\hline $\mathrm{R}^{2}$ & 0.491 \\
\hline
\end{tabular}

${ }^{* * *}$ Significant at $1 \% ;{ }^{* *}$ Significant at $5 \% ;$ 'Significant at $10 \%$.

Regarding the result of the variable reflecting industrialization, it can be explained by the fact that the exporting countries included in the study do not have a high level of industrialization, and the existing industrial activities have essentially outlets in the domestic market and are not very dynamic to export.

The coefficient of the variable WAEMU indicates that, ceteris paribus, trade flows with countries of the union are 3.6 times higher than trade with countries outside the zone. This result is quite close to those obtained by Rose [10] for the European Union and Diop [11] for WAEMU which assessed intra-union trade at triple of trade with non-member countries. However, it is higher than the estimation of Tsangarides et al. [12] which is 2.5.

Table 8 and Table 9 present the estimation of export potentials of Morocco and Senegal. Morocco has significant potential to export with respect to neighboring countries (Algeria, Tunisia), to European countries (Germany, Portugal, United Kingdom, Denmark), while this potential is saturated for Northern African countries such as Libya and Egypt and for European countries like Spain, France, Italy and The Netherlands. Regarding Sub-Saharan African countries, Morocco has saturated its trade potential with respect to Senegal and other countries of the sample with the exception of Cape Verde, Cameroon, South Africa, Tanzania and Mozambique.

The trade potential of Morocco is not sufficiently exploited vis-à-vis some Asian countries (Bangladesh, Singapore, and Japan) and Latin America (Ecuador).

The existence of a significant export potential of Morocco with respect to Northern African countries, with the exception of Libya and Egypt, is consistent with the results of Achy [13].

The export potential of Senegal is saturated with respect to West African countries except Nigeria. This result is consistent with recent trends in Senegal foreign trade characterized by increased trade with ECOWAS countries.

The potential of Senegal trade is very poorly exploited vis-à-vis Northern African countries such as Algeria and Libya and to a lesser extent Tunisia and Morocco.

The trade potential of Senegal is poorly exploited vis-à-vis some European countries (Germany, Denmark, and Russia), Asian countries (Pakistan, Saudi Arabia, Japan, Bangladesh, Malaysia, and South Korea), Latin American countries (Argentina, Brazil, and Mexico) and Canada.

\section{Conclusion}

The evolution of international trade from Senegal and Morocco during the last fifteen years is characterized by a 
Table 8. Trade flows and export potential of Morocco (Unit: millions of current dollars).

\begin{tabular}{|c|c|c|c|c|c|c|}
\hline & Exporting country & Importing country & Observed trade & Simulated trade & Adjusted trade & Trade potential \\
\hline 1 & Morocco & Cameroon & 7.80 & 9.64 & 12.81 & 11.22 \\
\hline 2 & Morocco & Italy & 587.90 & 475.84 & 635.00 & 555.42 \\
\hline 3 & Morocco & South Africa & 7.61 & 8.43 & 11.21 & 9.82 \\
\hline 4 & Morocco & Angola & 17.06 & 1.70 & 2.25 & 1.98 \\
\hline 5 & Morocco & Algeria & 52.58 & 644.47 & 930.25 & 787.36 \\
\hline 6 & Morocco & Saudi Arabia & 70.13 & 10.08 & 13.32 & 11.70 \\
\hline 7 & Morocco & Benin & 19.29 & 4.42 & 5.87 & 5.15 \\
\hline 8 & Morocco & Brazil & 267.12 & 20.51 & 26.60 & 23.55 \\
\hline 9 & Morocco & Canada & 82.04 & 57.65 & 76.53 & 67.09 \\
\hline 10 & Morocco & Kuwait & 6.82 & 3.87 & 5.14 & 4.51 \\
\hline 11 & Morocco & Portugal & 204.30 & 499.77 & 696.09 & 597.93 \\
\hline 12 & Morocco & Congo & 19.34 & 2.33 & 3.09 & 2.71 \\
\hline 13 & Morocco & Japan & 107.11 & 168.93 & 227.05 & 197.99 \\
\hline 14 & Morocco & The Netherlands & 311.74 & 190.29 & 251.26 & 220.77 \\
\hline 15 & Morocco & Malaysia & 2.57 & 2.04 & 2.71 & 2.37 \\
\hline 16 & Morocco & Tanzania & 0.45 & 0.44 & 0.58 & 0.51 \\
\hline 17 & Morocco & Turkey & 104.09 & 30.76 & 40.60 & 35.68 \\
\hline 18 & Morocco & France & 3465.80 & 1319.06 & 1393.54 & 1356.30 \\
\hline 19 & Morocco & Argentina & 41.94 & 1.53 & 2.02 & 1.77 \\
\hline 20 & Morocco & Singapore & 0.94 & 3.20 & 4.25 & 3.72 \\
\hline 21 & Morocco & Pakistan & 115.13 & 5.04 & 6.62 & 5.83 \\
\hline 22 & Morocco & Côte d'Ivoire & 29.22 & 10.59 & 14.05 & 12.32 \\
\hline 23 & Morocco & Bangladesh & 1.59 & 5.31 & 7.06 & 6.18 \\
\hline 24 & Morocco & Russia & 145.89 & 9.64 & 12.64 & 11.14 \\
\hline 25 & Morocco & United Kingdom & 730.46 & 1066.45 & 1528.15 & 1297.30 \\
\hline 26 & Morocco & Egypt & 31.62 & 24.61 & 32.70 & 28.65 \\
\hline 27 & Morocco & Iran & 46.42 & 4.99 & 6.60 & 5.80 \\
\hline 28 & Morocco & China & 91.64 & 53.28 & 70.62 & 61.95 \\
\hline 29 & Morocco & Thailand & 28.54 & 4.24 & 5.62 & 4.93 \\
\hline 30 & Morocco & Ghana & 17.81 & 2.10 & 2.78 & 2.44 \\
\hline 31 & Morocco & Ukraine & 2.77 & 3.79 & 5.03 & 4.41 \\
\hline 32 & Morocco & Nigeria & 22.50 & 11.22 & 14.89 & 13.05 \\
\hline 33 & Morocco & Kenya & 6.10 & 1.01 & 1.33 & 1.17 \\
\hline 34 & Morocco & Mexico & 49.29 & 10.05 & 13.31 & 11.68 \\
\hline 35 & Morocco & Libya & 20.99 & 5.61 & 7.44 & 6.52 \\
\hline 36 & Morocco & Qatar & 2.86 & 0.93 & 1.23 & 1.08 \\
\hline 37 & Morocco & Mozambique & 0.04 & 0.18 & 0.24 & 0.21 \\
\hline 38 & Morocco & Spain & 2422.73 & 1899.11 & 2555.72 & 2227.42 \\
\hline 39 & Morocco & Denmark & 3.32 & 91.34 & 122.76 & 107.05 \\
\hline 40 & Morocco & Cape Verde & 0.46 & 0.83 & 1.10 & 0.97 \\
\hline 41 & Morocco & South Korea & 36.03 & 17.64 & 23.40 & 20.52 \\
\hline 42 & Morocco & Ecuador & 0.03 & 0.92 & 1.23 & 1.08 \\
\hline 43 & Morocco & Senegal & 50.89 & 16.40 & 21.72 & 19.06 \\
\hline
\end{tabular}




\begin{tabular}{ccccccc} 
Continued & \multicolumn{7}{c}{} \\
\hline 44 & Morocco & Equatorial Guinea & 13.90 & 0.84 & 1.12 & 0.98 \\
45 & Morocco & Tunisia & 70.92 & 73.47 & 97.85 & 85.66 \\
46 & Morocco & Indonesia & 24.20 & 3.64 & 4.83 & 4.24 \\
47 & Morocco & Gabon & 14.52 & 1.67 & 2.22 & 1.95 \\
48 & Morocco & Togo & 15.59 & 1.82 & 2.41 & 2.11 \\
49 & Morocco & Germany & 351.06 & 592.44 & 823.66 & 708.05 \\
50 & Morocco & The Gambia & 10.51 & 0.49 & 0.65 & 0.57 \\
\hline
\end{tabular}

Table 9. Trade flows and export potential of Senegal (Unit: millions of current dollars).

\begin{tabular}{|c|c|c|c|c|c|c|}
\hline & Exporting country & Importing country & Observed trade & Simulated trade & Adjusted trade & Trade potentia \\
\hline 1 & Senegal & South Africa & 0.67 & 1.29 & 5.00 & 3.14 \\
\hline 2 & Senegal & Greece & 24.41 & 1.71 & 6.45 & 4.08 \\
\hline 3 & Senegal & Japan & 11.26 & 14.93 & 60.26 & 37.59 \\
\hline 4 & Senegal & China & 11.99 & 4.62 & 17.89 & 11.26 \\
\hline 5 & Senegal & Equatorial Guinea & 2.69 & 0.14 & 0.53 & 0.33 \\
\hline 6 & Senegal & Canada & 0.85 & 5.92 & 23.31 & 14.62 \\
\hline 7 & Senegal & Tunisia & 1.41 & 2.27 & 8.79 & 5.53 \\
\hline 8 & Senegal & Mexico & 0.71 & 1.26 & 4.88 & 3.07 \\
\hline 9 & Senegal & Singapore & 0.40 & 0.32 & 1.22 & 0.77 \\
\hline 10 & Senegal & Ghana & 3.78 & 0.52 & 2.00 & 1.26 \\
\hline 11 & Senegal & Brazil & 0.13 & 4.67 & 18.29 & 11.48 \\
\hline 12 & Senegal & Argentine & 0.01 & 0.29 & 1.12 & 0.71 \\
\hline 13 & Senegal & Poland & 0.90 & 1.21 & 4.68 & 2.95 \\
\hline 14 & Senegal & Cape Verde & 3.22 & 0.75 & 2.88 & 1.81 \\
\hline 15 & Senegal & Togo & 15.20 & 1.41 & 5.37 & 3.39 \\
\hline 16 & Senegal & France & 123.84 & 37.92 & 149.74 & 93.83 \\
\hline 17 & Senegal & Israel & 0.15 & 0.92 & 3.57 & 2.25 \\
\hline 18 & Senegal & Malaysia & 0.21 & 0.18 & 0.69 & 0.43 \\
\hline 19 & Senegal & Bangladesh & 0.54 & 0.47 & 1.82 & 1.14 \\
\hline 20 & Senegal & The Gambia & 78.34 & 11.33 & 42.06 & 26.69 \\
\hline 21 & Senegal & Benin & 14.08 & 3.16 & 12.15 & 7.65 \\
\hline 22 & Senegal & Egypt & 0.24 & 0.69 & 2.66 & 1.68 \\
\hline 23 & Senegal & Germany & 3.50 & 23.02 & 96.78 & 59.90 \\
\hline 24 & Senegal & Viet Nam & 0.70 & 0.32 & 1.24 & 0.78 \\
\hline 25 & Senegal & Morocco & 18.46 & 9.66 & 37.91 & 23.78 \\
\hline 26 & Senegal & The Netherlands & 16.75 & 7.08 & 27.57 & 17.33 \\
\hline 27 & Senegal & Denmark & 0.50 & 4.05 & 15.84 & 9.95 \\
\hline 28 & Senegal & Algeria & 0.20 & 4.16 & 16.28 & 10.22 \\
\hline 29 & Senegal & Pakistan & 0.05 & 0.42 & 1.62 & 1.02 \\
\hline 30 & Senegal & Spain & 75.15 & 27.71 & 110.43 & 69.07 \\
\hline 31 & Senegal & Congo & 9.75 & 0.37 & 1.41 & 0.89 \\
\hline 32 & Senegal & Namibia & 0.47 & 0.03 & 0.13 & 0.08 \\
\hline 33 & Senegal & Nigeria & 4.31 & 1.86 & 7.17 & 4.52 \\
\hline 34 & Senegal & Qatar & 0.00 & 0.03 & 0.12 & 0.08 \\
\hline
\end{tabular}




\begin{tabular}{ccccccc} 
Continued & \multicolumn{7}{c}{} \\
\hline 35 & Senegal & Kenya & 0.75 & 0.11 & 0.44 & 0.28 \\
36 & Senegal & Côte d'Ivoire & 36.20 & 12.93 & 50.48 & 31.70 \\
37 & Senegal & Gabon & 7.27 & 0.28 & 1.08 & 0.68 \\
38 & Senegal & Angola & 2.03 & 0.28 & 1.09 & 0.69 \\
39 & Senegal & Libya & 0.01 & 0.11 & 0.42 & 0.26 \\
40 & Senegal & Iran & 0.17 & 0.37 & 1.41 & 0.89 \\
41 & Senegal & Russia & 0.03 & 0.61 & 2.37 & 1.49 \\
42 & Senegal & South Korea & 2.06 & 1.54 & 5.95 & 3.74 \\
43 & Senegal & Cameroon & 9.64 & 1.38 & 61.81 & 3.34 \\
44 & Senegal & Italy & 67.47 & 16.14 & 38.98 \\
45 & Senegal & Indonesia & 0.98 & 0.37 & 0.47 & 0.90 \\
46 & Senegal & Kuwait & 0.00 & 0.12 & 1.33 & 0.30 \\
47 & Senegal & Saudi Arabia & 0.13 & 0.35 & 1.53 & 0.84 \\
48 & Senegal & Thailand & 2.25 & 0.40 & 174.01 & 0.96 \\
49 & Senegal & United Kingdom & 7.25 & 38.82 & 23.78 & 106.41 \\
50 & Senegal & Portugal & 10.26 & 6.09 & 14.94 \\
\hline
\end{tabular}

trend towards a reorientation of trade flows to African countries for Senegal and to emerging countries for Morocco. Trade between the two countries is characterized by an imbalance in favor of Morocco. The Senegal coverage rate of imports from Morocco by exports is very low and was, on average, during the first decade of the 2000s, below the $15 \%$ threshold.

While Morocco has demonstrated aggressive exports to Senegal more than its estimated potential, Senegal exports to Morocco are much lower than the estimated potential exports, the gap being about $22.4 \%$.

Morocco has non-exploited export potential, which is significant with respect to neighboring countries (Algeria, and Tunisia), to several European countries, to some West African countries (Cape Verde), to Central African countries (Cameroon) and to Eastern African countries (Mozambique, and Tanzania) as well as to Asian countries (Singapore, Bangladesh, and Japan).

Morocco and Senegal would benefit from further exploitation of their export potential within the African continent and in other regions. Better support for exporting companies through specific actions to penetrate the markets of partner countries (setting export targets by the State and the private sector, targeted support to successful exporting companies through market surveys carried out by the State or export promotion institutions, easier access to bank credits, etc.) could improve the use of the export potential.

This study may be extended through a finer estimate of export potential which distinguishes the main exported products.

\section{References}

[1] Omilaloa, B. (2011) To What Extent Are Regional Trade Arrangements in Africa Fulfilling the Conditions for Successful RTA's. Journal of African Studies and Development, 36, 105-113.

[2] Seid, H.E. (2013) Regional Integration and Trade in Africa: Augmented Gravity Model Approach. The Horn Economic and Social Policy Institute.

[3] CNUCED (2013) Le développement économique en Afrique. Commerce intra-africain: libérer le dynamisme du secteur privé. Report, United Nations.

[4] Tinbergen, J. (1962) Shaping the World Economy: Suggestions for an International Economic Policy. The Twentieth Century Fund.

[5] Fontagné, L., Pajot, M. and Pasteels, J.-M. (2001) Potentiels de commerce entre économies hétérogènes: Un petit mode d'emploi des modèles de gravité. Centre du Commerce International CNUCED/OMC, November.

[6] Anderson, J.E. (1979) A Theoretical Foundation for the Gravity Equation. American Economic Review, 69, $106-116$.

[7] Bergstrand, J.H. (1985) The Gravity Equation in International Trade: Some Microeconomic Foundations and Empirical Evidence. Review of Economics and Statistics, 67, 474-481. http://dx.doi.org/10.2307/1925976 
[8] Bergstrand, J.H. (1989) The Generalized Gravity Equation, Monopolistic Competition, and the Factor-Proportions Theory of International Trade. Review of Economics and Statistics, 23, 143-153. http://dx.doi.org/10.2307/1928061

[9] Deardorff, A.V. (1998) Does Growth Encourage Factor Price Equalization? University of Michigan Discussion, Paper 382.

[10] Rose, A.K. (2000) One Money One Market: Estimating the Effect of Common Currencies on Trade. Economic Policy, 15, 7-46. http://dx.doi.org/10.1111/1468-0327.00056

[11] Diop, A.C. (2007) L’UEMOA et la perspective d'une zone monétaire unique de la CEDEAO: Les enseignements d'un modèle de gravité. BCEAO Study and Research Document, April.

[12] Tsangarides, C., Ewenzyck, P., Hulej, M. and Quresh, M.S. (2008) Are Arica's Currency Unions Good for Trade? IMF Staff Papers, $\mathbf{5 6 .}$

[13] Achy, L. (2006) Le commerce en Afrique du Nord. Evaluation du potentiel de l’intégration régionale en Afrique du Nord. United Nations Economic Commission for Africa, April. 